\title{
First genotyping of Giardia lamblia from human and animal feces in Argentina, South America
}

\author{
Marta C Minvielle, Nora B Molina, Daniela Polverino, Juan A Basualdo/ ${ }^{+}$ \\ Cátedra de Microbiología y Parasitología, Facultad de Medicina, Universidad Nacional de La Plata, Calle 60 y 120 s/n, CP 1900 , \\ La Plata, Argentina.
}

The purpose of this study was to investigate the genotypes of Giardia lamblia from human and animal feces and their epidemiological and clinical characteristics in Argentina, South America. Seventy isolates, 60 from humans (adults and children), eight from dogs and two from cows were processed by polymerase chain reaction-restriction fragment length polymorphism. Data corresponding to demographic, socio-cultural and environmental variables and presencel absence of signs/symptoms were collected. The triosephosphate isomerase gene was amplified from 43 (71.66\%) of the 60 human fecal samples. Among these, 3/43 (6.98\%) were genotype AII and 40/43 (93.02\%) were genotype B. Assemblage AII was detected in three children who lived together in a shantytown and they were oligosymptomatic and none had diarrhea. This genotype was not found in animals. Genotype B showed a high prevalence in both adults and children. It was also found in polysymptomatic people, many of whom presented diarrhea. It was also found only in one dog. The present study represents the first contribution to the knowledge of $\mathrm{G}$. lamblia genotypes in Argentina.

Key words: Giardia - genotypes - Argentina - South America.

Giardia lamblia is a flagellated eukaryotic unicellular microorganism that produces diarrheal disease throughout the world (Adam 2001). This intestinal protozoan has been found in a wide range of mammals and has been accepted as a zoonotic agent (Hopkins et al. 1997, McGlade et al. 2003). In recent decades, molecular classification has been implemented to identify this parasite protozoan and to understand the pathogenesis and host range.

Small-subunit rRNA, triosephosphate isomerase (tpi), beta giardin and glutamate-dehydrogenase genomic sequences have been previously studied to mainly permit better identification and comparisons of G. lamblia isolates (Mahbubani et al. 1998, Monis et al. 1999, Adam 2000, Caccio et al. 2002, Lu et al. 2002, Rimhanen-Finne et al. 2002). All of these studies have confirmed the division of human isolates into two major groups called genotype A (or Polish) and genotype B (or Belgian) (Mayrhofer et al. 1995). In addition to their genetic differences, both genotypes can have important number of biological differences. For example, genotype B was significantly more pathogenic in human volunteer infections than genotype A (Adam 2001). Homan and Mank (2001) reported a strong correlation between the mild, intermittent type of diarrhea and assemblage A and severe, actual/persistent diarrhea and assemblage B. However, Eligio-García et al. (2005) and Lalle et al. (2005) did not find any correlation between symptoms and genotype.

Finacial support: Agencia Nacional de Promoción Científica y Tecnológica, Comisión de Investigaciones Científica de la provincia de Buenos Aires, Universidad Nacional de La Plata

+ Corresponding author: jabasua@atlas.med.unlp.edu.ar

Received 31 October 2007

Accepted 12 February 2008
Genotyping studies have identified G. lamblia isolates from dogs, some of which were found to be genetically identical to those obtained from humans (van Keulen et al. 2002). Studies on G. lamblia obtained from cattle have proved that some isolates belong to genotype $\mathrm{E}$ and others to genotype A, and only the latter can cause human infection (O’ Handley et al. 2000).

About 200 million people in the world are infected with G. lamblia and each individual eliminates up to 900 million cysts per day (Crompton 1999). Higher prevalence is found in tropical and subtropical areas, where $G$. lamblia affects up to $30 \%$ of the population. In epidemiological studies carried out in Argentina, a prevalence of $10 \%$ has been found in urban areas and $34 \%$ in shantytowns (Gamboa et al. 2003). In rural areas, giardiasis frequency has been close to 4\% (Minvielle et al. 2004). In animals from this region the reported prevalence is $7.5 \%$ in cattle, $18.6 \%$ in dogs, and 3.9\% in rodents (Pezzani et al. 2003). Presence of G. lamblia has also been observed in environmental samples (soil and water) from different areas of Argentina (Pierangeli et al. 2003).

In Argentina, current methods for the detection of this parasite both in human and animal feces and in environmental samples are usually based on morphological recognition by light microscopy or the use of indirect immunofluorescence with monoclonal antibodies. No previous studies on the use of molecular techniques for G. lamblia in our country were found in the revised bibliography. The aim of this study was to determine the genotype of G. lamblia isolates from human and animal feces (dogs and cows) from La Plata (LP) and General Mansilla (GM), Argentina by using polymerase chain reactionrestriction fragment length polymorphism (PCR-RFLP) technique and analyzing their clinical and epidemiological characteristics. 


\section{SUBJECTS, MATERIALS AND METHODS}

Samples - Fecal samples from 60 (1 to 33-year old) people and ten animals ( 2 cows and 8 dogs), in which cysts had been detected by light microscopy were analyzed by the modified Telemann technique (Gamboa et al. 2003), including lugol staining. Only one time-related inclusion criterion was considered: samples obtained in population studies (people with and without signs/ symptoms) in 2003-2004. All samples were preserved in $5-10 \%$ formaldehyde. Participants and legal guardians were requested to give their voluntary consent for the perfonmance of this study.

Forty-nine human fecal samples from GM, a rural town $90 \mathrm{~km}$ from Buenos Aires, and 11 from a shantytown in LP, $60 \mathrm{~km}$ from Buenos Aires, were collected. The fecal samples of six dogs from GM, two dogs from LP and two cows from GM were included.

Specific data about risk factors for parasitic infection, including demographic, socio-cultural, and environmental variables, and as well as the presence/absence of signs/symptoms were collected from each human participant. Data corresponding to the following variables were selected: demographic: sex and age; socio-cultural: residence (urban or rural); sanitary condition of the houses (good, medium or poor). "Good" included masonry building, cement/tile floors, fully-equipped bathroom, running water, sewage system, and garbage collection. "Medium" included masonry, cement/tile floors, fullyequipped/half equipped bathroom, home water pump, cesspool and no garbage collection (garbage buried or burnt). "Poor" included wooden/cardboard and/or tin building, dirt floors, latrine, water from a community pump or tap, and open-sky garbage disposal. Overcrowding (yes or no) meant three or more people sleeping in the same room. Environmental: house flooding (never, sometimes, or frequently), where "sometimes" flooding was up to twice a year and "frequently" flooding ocurred three or more times a year. Clinical: presence/absence of signs/symptoms (yes or no), where diarrhea, vomiting, abdominal pain, appetite loss, weakness and sleeping disorders were registered. Parasitic: presence of other parasites in the feces and perianal swab sampling.

Cyst purification and disruption - $10 \mathrm{ml}$ of feces filtered through gauze were centrifuged for $5 \mathrm{~min}$ at $200 \mathrm{~g}$; $5 \mathrm{ml}$ of phosphate-buffered saline (PBS) were added and centrifuged for $5 \mathrm{~min}$ at $200 \mathrm{~g}$. The supernatant was discarded; $3 \mathrm{ml}$ of PBS and $4 \mathrm{ml}$ of sucrose solution (density 1.275) were added. All samples were centrifuged for $5 \mathrm{~min}$ at $200 \mathrm{~g}$. The sucrose phase was aspired and transferred to another tube with two volumes of PBS. Cysts were concentrated by centrifugation at $250 \mathrm{~g}$ for $5 \mathrm{~min}$. Sediment was resuspended with PBS and stored at $4^{\circ} \mathrm{C}$ until use.

Cysts were subjected to six cycles of freezing-thawing $\left(-80^{\circ} \mathrm{C} /+80^{\circ} \mathrm{C}, 30 \mathrm{~min}\right)$ and incubated with Proteinase $\mathrm{K}$ $(1 \mathrm{mg} / \mathrm{ml})$ and lysis buffer $(\mathrm{NaCl} 0.15 \mathrm{M}$, EDTA $0.1 \mathrm{M}$, SDS $0.5 \%, \mathrm{pH} 7-8$ ) at $37^{\circ} \mathrm{C}$ for $24 \mathrm{~h}$ (Eligio-García et al. 2002, Polverino et al. 2004). This suspension was stored at $-20^{\circ} \mathrm{C}$ until DNA isolation.

DNA isolation - All buffers and reagents used in this step were provided in the Qiagen ${ }^{\circledR}$ spin-column miniKit (QIAamp DNA stool minikit, Cat. 51504). DNA extraction was performed on $200 \mu \mathrm{l}$ samples. Two modifications of this protocol were employed: lysis temperature was increased to $95^{\circ} \mathrm{C}$; the $\mathrm{AE}$ elution buffer was incubated for $10 \mathrm{~min}$.

PCR-RFLP - The tpi gene was amplified according to Amar et al. (2002) (Table I) with modifications: $3 \mathrm{mM}$ $\mathrm{MgCl}_{2}, 0.1 \mu \mathrm{g} / \mu \mathrm{l}$ bovine serum albumin and $0.1 \mathrm{U} / \mu \mathrm{l} \mathrm{Taq}$ DNA polymerase (Invitrogen). All reactions involved an initial denaturation step at $94^{\circ} \mathrm{C}(4 \mathrm{~min}), 30$ cycles at $94^{\circ} \mathrm{C}$ $(30 \mathrm{~s}), 52^{\circ} \mathrm{C}(30 \mathrm{~s})$ and $72^{\circ} \mathrm{C}(1 \mathrm{~min})$, with a final elongation step at $72^{\circ} \mathrm{C}(10 \mathrm{~min})$. A Techgene thermocycler (Techne, Germany) was used. Both positive and negative controls were included in each PCR to validate results (Molina et al. 2007). Positive DNA control genotypes A

TABLE I

Primers sequences and amplicons of polymerase chain reaction (PCR) and restriction fragment length polymorphism (RFLP) products

\begin{tabular}{|c|c|c|}
\hline PCR & Genotype A & Genotype B \\
\hline First step & $\begin{array}{l}\text { TPIA-FI: } \\
\text { CGAGACAAGTGTTGAGATG } \\
\text { TPIA-R: } \\
\text { GGTCAAGAGCTTACAACACG }\end{array}$ & $\begin{array}{l}\text { TPIB-FI: } \\
\text { GTTGCTCCCTCCTTTGTGC } \\
\text { TPIB-R: } \\
\text { CTCTGCTCATTGGTCTCGC }\end{array}$ \\
\hline Products & 576 bp & 208 bp \\
\hline Second step & $\begin{array}{l}\text { TPIA-FII: } \\
\text { CCAAGAAGGCTAAGCGTGC } \\
\text { TPIA-R: } \\
\text { GGTCAAGAGCTTACAACACG }\end{array}$ & $\begin{array}{l}\text { TPIB-FII: } \\
\text { GCACAGAACGTGTATCTGG } \\
\text { TPIB-R: } \\
\text { CTCTGCTCATTGGTCTCGC }\end{array}$ \\
\hline Products & 476 bp & 140 bp \\
\hline $\begin{array}{l}\text { RFLP } \\
\text { Rsa I }\end{array}$ & $\begin{array}{l}\text { AII } \\
235 \mathrm{bp} \\
202 \mathrm{bp} \\
39 \mathrm{bp}\end{array}$ & \\
\hline
\end{tabular}


and B courtesy of Dr. Van Keulen, Cleveland University, and bidistillated water as negative control were used in each PCR. RFLP analysis was performed as described by Amar et al.(2002). Amplification was assessed by electrophoresis of PCR samples on $1.5 \%$ or $3.2 \%$ agarose gels depending on the expected sizes of amplified DNA.

\section{RESULTS}

The tpi gene was amplified from $43(71.66 \%)$ of the analyzed 60 human fecal samples (Fig. 1a, b). Among humans isolates, $40 / 43(93.02 \%)$ were genotype B and $3 / 43(6.98 \%)$ were genotype AII. Genotype classification and its relationship with host sex, age and animal ownership are shown in Tables II and III. Only 1/10 (10\%) animal isolates could be genotypified.

Genotype AII was detected in three people from LP and genotype B was present in five people from LP and in 35 from GM. All samples with genotype AII were from children ( $\leq 14$ years old), while genotype $\mathrm{B}$ was present in children as well as adults. Concerning sex, $66.66 \%$ of genotype AII and $62.57 \%$ of genotype B were found in males. Among children, $92.30 \%$ of boys and $92.85 \%$ of girls presented genotype B.

Three individuals presenting genotype AII lived in urban areas and had poor sanitary conditions, while $87.5 \%$ of the people with genotype B lived in rural areas and had either poor $(60 \%-24 / 40)$, medium $(30 \%-12 / 40)$ or good $(10 \%-4 / 40)$ sanitary conditions. Overcrowding was observed in all cases of genotype AII, while only $30 \%$ $(12 / 40)$ had this condition among genotype B. Houseflooding was never present among individuals with

a

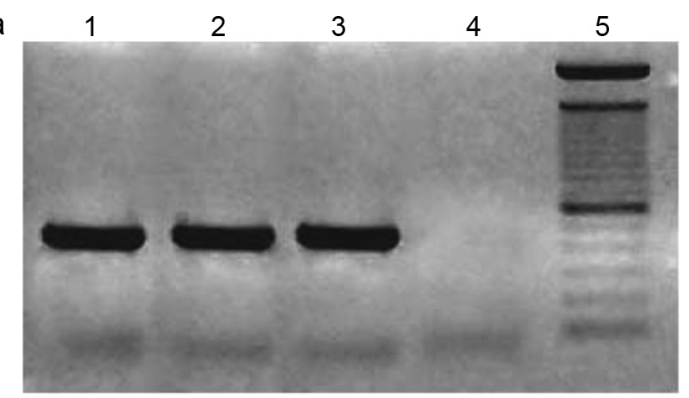

b

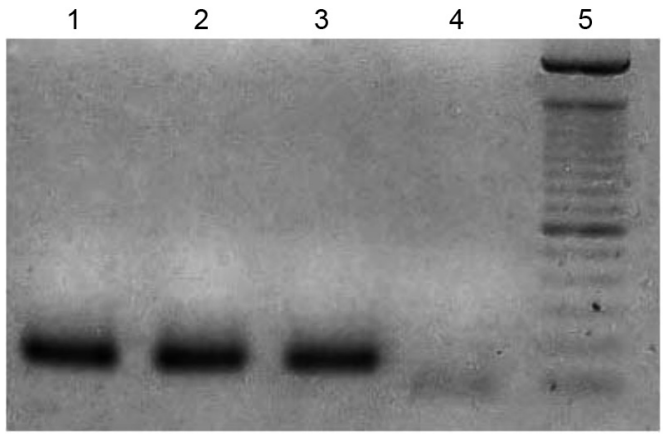

Fig. 1: agarose gel stained with ethidium bromide corresponding to PCRII. a: lanes - 1: positive control; 2 - 3: genotypes A of human feces; 4: negative control; 5: molecular weight marker (100 bp). b: lanes - 1: positive control; 2 - 3: genotypes B of human feces; 4: negative control; 5: molecular weight marker (100 bp).
TABLE II

Genotype classification and its relationship with host sex, age, animal ownership in children from a shantytown in La Plata, Argentina

\begin{tabular}{llccc}
\hline Code $^{a}$ & sex & genotype & $\begin{array}{c}\text { age } \\
\text { (years) }\end{array}$ & $\begin{array}{c}\text { animal } \\
\text { ownership }\end{array}$ \\
\hline 1 & male & B & 4 & $\operatorname{dog}^{b}$ \\
2 & male & B & 3 & $\operatorname{dog}^{b}$ \\
3 & male & B & 5 & dog \\
4 & male & B & 3 & dog \\
5 & male & AII & 7 & - \\
6 & female & AII & 13 & - \\
7 & male & AII & 11 & - \\
8 & female & B & 8 & - \\
\hline
\end{tabular}

$a$ : codes 3 and 4 are siblings, as well as 5,6 and $7 ; b$ : dog in which G. lamblia was detected by light microscopy although tpi gene was not amplified.

genotype AII. Individuals with genotype B had frequent flooding in $40 \%(16 / 40)$ of the cases, sometimes in $20 \%$ $(8 / 40)$ and never in $40 \%(16 / 40)$.

In order to determine the presence of other parasites, we found that 15 out of 43 people were only infected with G. lamblia (14 from GM and 1 from LP). All genotype-AII infected people were coinfected with Blastocystis hominis. In the case of genotype B, 37.5\% (15/40) were coinfected with Enterobius vermicularis, 32.5\% (13/40) with B. hominis, $17.5 \%$ (7/40) with Entamoeba coli, 10\% (4/40) with Ascaris lumbricoides, 5\% (2/40) with Trichuris trichiura, and 5\% (2/40) with Strongyloides stercoralis.

All people with genotype AII reported only weakness and appetite loss. Those with genotype B reported abdominal pain $24 / 40(60 \%)$, diarrhea 20/40 (50\%), appetite loss $19 / 40(47.5 \%)$, sleeping disorders $15 / 40$ $(37.5 \%)$, weakness $13 / 40(32.5 \%)$, and vomiting $10 / 40$ $(25 \%)$. Among people infected only with G. lamblia (100\% genotype B), 9/15 (60\%) reported diarrhea, $7 / 15$ (46.66\%) abdominal pain, 6/15 (40\%) sleeping disorders, 6/15 (40\%) weakness, $6 / 15(40 \%)$ appetite loss, and 5/15 $(33.33 \%)$ vomiting. Two children $(13.33 \%)$ reported no signs/symptoms. Among adults studied (all genotype B), one female who had S. stercolaris and G. lamblia, reported sleeping disorders and appetite loss; a male coinfected with $B$. hominis reported sleeping disorders, abdominal pain and appetite loss; and a female with E. coli, E. vermicularis and $B$. hominis had no signs/symptoms.

\section{DISCUSSION}

The present study provides, for the first time in our country, information on the distribution of G. lamblia genotypes A and B in both humans and animals from LP and GM. The proportion of samples in which the tpi gene could not be amplified was higher than that reported by Amar et al. (2002), using the same primers. In our study, this could be explained by the presence of PCR inhibitors in some of the fecal samples resulting in prevention of amplification. The failures in the amplification would derive from the low quality DNA of the samples, either due 
TABLE III

Sex, age and animal ownership among adults from General Mansilla, Argentina, who amplified the Giardia lamblia triosephosphate isomerase gene. All were genotype B

\begin{tabular}{|c|c|c|c|}
\hline Code $^{a}$ & $\operatorname{sex}$ & age & animal \\
\hline 9 & female & 29 & $\operatorname{dog}^{b}$ \\
\hline 10 & female & 33 & $\operatorname{dog}$ \\
\hline 11 & male & 26 & $\operatorname{dog}$ \\
\hline 12 & male & 2 & dog, $\operatorname{cow}^{c}$ \\
\hline 13 & female & 4 & $\operatorname{dog}, \operatorname{cow}^{c}$ \\
\hline 14 & male & 1 & $\operatorname{dog}$ \\
\hline 15 & male & 5 & - \\
\hline 16 & female & 3 & $\operatorname{dog}^{a}$ \\
\hline 17 & male & 8 & $\operatorname{dog}^{a}$ \\
\hline 18 & male & 3 & - \\
\hline 19 & female & 4 & - \\
\hline 20 & male & 3 & $\operatorname{dog}$ \\
\hline 21 & male & 4 & $\operatorname{dog}$ \\
\hline 22 & female & 6 & - \\
\hline 23 & female & 3 & $\operatorname{dog}^{b}$ \\
\hline 24 & male & 4 & $\operatorname{dog}$ \\
\hline 25 & female & 4 & - \\
\hline 26 & female & 2 & - \\
\hline 27 & female & 7 & - \\
\hline 28 & male & 2 & - \\
\hline 29 & male & 9 & $\operatorname{dog}$ \\
\hline 30 & male & 12 & $\operatorname{dog}$ \\
\hline 31 & male & 9 & - \\
\hline 32 & female & 8 & - \\
\hline 33 & male & 8 & $\operatorname{dog}$ \\
\hline 34 & female & 7 & dog \\
\hline 35 & female & 10 & $\operatorname{dog}$ \\
\hline 36 & male & 3 & dog \\
\hline 37 & male & 4 & $\operatorname{dog}$ \\
\hline 38 & male & 2 & $\operatorname{dog}^{b}$ \\
\hline 39 & male & 3 & $\operatorname{dog}^{b}$ \\
\hline 40 & male & 2 & $\operatorname{dog}^{b}$ \\
\hline 41 & male & 3 & $\operatorname{dog}^{b}$ \\
\hline 42 & male & 5 & $\operatorname{dog}$ \\
\hline 43 & male & 9 & dog \\
\hline
\end{tabular}

$a$ : codes 10 and 11 lived together; 25 - 27, 29 - 32, 38 - 43 are siblings; $b$ : dog in which $G$. lamblia was detected by light microscopy and was genotype B; $c$ : dog/cow in which $G$. lamblia was detected by light microscopy although tpi gene was not amplified.

to their degrading in time or because of chemical modifications caused by several substances, formalin among them (Molina et al. 2007). Also, these failures could be the result of the fact that the proportion of DNA in the feces samples was not enough to counteract the effect of the inhibitors that would have co-purified with the nucleic acids (Molina et al. 2007).

Surveys in several countries showed a diverse prevalence of genotypes A and B. Studies carried out in Germany, China, Uganda, New Zealand, Egypt, Portugal, and Mexico reported a predominance of genotype A ( $\mathrm{Ka}$ ranis \& Ey 1998, Yong et al. 2000, Graczyk et al. 2002, Learmonth et al. 2003, Ceu Sousa \& Poiares da Silva 2004, El Shazly et al. 2004, Lalle et al. 2005). On the other hand, Read et al. (2004) studied 23 people in Australia and found genotype B in 14, AII in 5, and AI in 4 individuals. In Canada, Guy et al. (2004) found 9 genotype B isolates, 3 genotype A isolates and 3 mixed (genotype A + genotype B). Results reported in our study agree with those from studies in Bangladesh published by $\mathrm{Ng}$ et al. (2005). They found 32 genotype $\mathrm{B}$ and 3 genotype $\mathrm{A}$ isolates. Results from all studies are not strictly comparable since amplifications were done on different G. lamblia genes and, in some of them, the populations were different, i.e., they were limited to symptomatic individuals.

Genotype AII was found only in children and genotype $B$ in both adults and children, although this difference cannot be considered significant. As regards sex, the distribution frequency of the genotypes was similar in both.

In the animals studied, genotype B was detected in only one canine sample. However, a more detailed study about the zoonotic transmission of this parasitosis should include more samples as well as the analysis of dog genotypes (C, D) and livestock genotype (E). Thompson (2000) stated that in rural environments the transmission of dog genotypes occurs more frequently than in urban environments. In his study, the dog had the zoonotic genotype and lived in a rural area. In studies of $G$. lamblia isolated from cattle, genotype E was detected with a prevalence between 56 and 57\% (O' Handley et al. 2000). This genotype has no zoonotic risk (Matsubayashi et al. 2005). In this study, there was no amplification from cattle feces.

Overcrowding was present in three people infected with genotype AII, that enabled us to hypothesize the possibility of inter-human transmission. Most people with genotype B showed no overcrowding although house flooding was frequent, suggesting the possibility of transmission from a contaminated source such as water or food.

Three people with genotype-AII G. lamblia reported appetite loss and weakness. None of them exhibited diarrhea, abdominal pain, sleeping disorders or vomiting, symptoms that were found in people with genotype-B. Only two people with genotype B reported no signs/symptoms.

The results of this study correlated genotype AII with oligosymptomatic giardiasis profiles and genotype B with asyntomatic/polysyntomatic profiles. People infected with genotype B are likely to seek medical advice while those with genotype AII are not, resulting in slow deterioration of their own health status, due to alterations in the nutrient absorption caused by G. lamblia (Read et al. 2002).

Amar et al. (2002) determined that genotype B was responsible for a diarrheal outbreak in a daycare center in England. However, a longitudinal study carried out in Australia by Read et al. (2002) reported that children infected with genotype A had a 26-fold greater risk of having diarrhea. In the Netherlands, Homan and Mank (2001) found that genotype B infection was associated with chronic diarrhea, while genotype A infections were related to intermittent diarrhea. Ceu Souza and Poiares da Silva (2004) and Eligio García et al. (2002) found no correlation between digestive manifestations and genotypes. Our study included people with and without symptoms since we hypothesized that selecting symptomatic patients only would not have shown the true prevalence 
of G. lamblia and the epidemiological role of the different genotypes. Oligo/asymptomatic people continue to attend school, the daycare center and workplace, producing localized endemic focuses.

In conclusion, genotype AII showed a low prevalence and was detected in three children who lived together in a poor home in LP. The children were oligosymptomatic and none had diarrhea. This genotype was not found in animals. Genotype B showed a high prevalence in both adults and children. It was found in polysymptomatic people, many of whom presented diarrhea. It was found in only one animal (dog). Transmission may have occurred through a common source of infection since it was found in people from different homes sharing the same water supply and experiencing house flooding. Studies carried out with a higher number of samples, both human and animal, coming from different areas will increase our understanding of the epidemiology of giardiasis in Argentina.

\section{ACKNOWLEDGEMENT}

To Laura Cipolla for her help in the translator of the manuscript.

\section{REFERENCES}

Adam RD 2000. The Giardia lamblia genome. Int J Parasitol 30: 475-484.

Adam RD 2001. Biology of Giardia lamblia. Clin Microbiol Rev 14: 447-475.

Amar C, Dear P, Pedraza Diaz S, Looker N, Linnae E, McLauchlin J 2002. Sensitive PCR-Restriction Fragment Length Polymorphism assay for detection and genotyping of Giardia duodenalis in human feces. J Clin Microbiol 40: 446-452.

Caccio E, Pinter R, Fantini I, Mezzaroma H, Pozio E 2002. Human infection with Cryptosporidium felis: case report and literature review. Emerg Infect Dis 8: 85-86.

Ceu Souza M, Poiares da Silva J 2004. Characterization of human isolates of Giardia lamblia from Portugal. Int $J$ Infect Dis 8 (Suppl. 1): 218.

Crompton DWT 1999. How much human helminthiasis is there in the world? J Parasitol 85: 397-403.

Eligio-García L, Cortes-Campos A, Jimenez-Cardoso E 2005. Genotype of Giardia intestinalis isolates from children and dogs and its relationship to host origin. Parasitol Res 97: 1-6.

Eligio-García L, Galván S, Jiménez-Cardoso E 2002. Distancia filogenética de aislados de Giardia intestinalis de niños sintomáticos y asintomáticos. Rev Invest Clin 54: 113-118.

El-Shazly A, Mowafy N, Soliman M, El-Bendary M, Morsy A, Ramadan N, Arafa W 2004. Egyptian genotyping of Giardia lamblia. $J$ Egypt Soc Parasitol 34: 265-280.

Gamboa M, Basualdo J, Córdoba M, Pezzani B, Minvielle M, Lahitte H 2003. Distribution of intestinal parasitoses in relation to environmental and sociocultural parameters in La Plata, Argentina. $J$ Helminthol 77: 15-20.

Graczyk T, Bosco-nizayi J, Ssebide B, Thompson R, Read C, Cranfield M 2002. Anthropozoonotic Giardia duodenalis genotype (assemblage) a infections in habitats of free-ranging human-habituated gorillas, Uganda. J Parasitol 88: 905-909.

Guy R, Xiao C, Horgen P 2004. Real time PCR assay for detection and genotype differentiation of Giardia lamblia in stool specimens. J Clin Microbiol 42: 3317-3320.
Homan W, Mank T 2001. Human giardiasis: genotype linked differences in clinical symptomatology. Int J Parasitol 31: 822-826.

Hopkins RM, Meloni BP, Groth DM, Wetherall JD, Reynoldson JA, Thompson RC 1997. Ribosomal RNA sequencing reveals differences between the genotypes of Giardia isolates recovered from humans and dogs living in the same locality. J Parasitol 83: 44-51.

Karanis P, Ey PL 1998. Characterization of axenic isolates of Giardia intestinalis established from humans and animals in Germany. Parasitol Res 84: 442-449.

Lalle M, Jimenez-Cardoso E, Caccio S, Pozio E 2005. Genotyping of Giardia duodenalis from humans and dogs from Mexico using a beta-giardin nested polymerase chain reaction assay. J Parasitol 91: 203-205.

Learmonth J, Ionas G, Pita A, Cowie R 2003. Identification and genetic characterization of Giardia and Cryptosporidium strains in human and dairy cattle in Waikato region of New Zealand. Water Sci Technol 47: 21-26.

Lu S, Li J, Zhang Y, Wen J, Wang F 2002. The intraspecific difference of triose phosphate isomerasa ( $\mathrm{tim}$ ) gene from Giardia lamblia. Chin Med J 115: 763-766.

Mahbubani MH, Schaefer FW, Jones DD, Bej AK 1998. Detection of Giardia in environmental waters by immuno-PCR amplification methods. Curr Microbiol 36: 107-113.

Matsubayashi M, Kimata I, Abe N 2005. Identification of genotypes of Giardia intestinalis isolates from humans and calf in Japan. $J$ Vet Med Sci 67: 337-340.

Mayrhofer G, Andrews R, Ey P, Chilton N 1995. Division of Giardia isolates from humans into two genetically distinct assemblages by electrophoresic analysis of enzymes encoded at 27 loci and comparison with Giardia muris. Parasitology 111: 11-17.

McGlade TR, Robertson ID, Elliot AD, Thompson RCA 2003. High prevalence of Giardia detected in cats by PCR. Vet Parasitol 110: 197-205.

Minvielle M, Pezzani B, Cordoba M, De Luca M, Apezteguía M, Basualdo J 2004. Epidemiological survey of Giardia spp and Blastocystis hominis in an Argentinian rural community. Korean $J$ Parasitol 42: 61-66.

Molina N, Polverino D, Minvielle M, Basualdo J 2007. PCR amplification of triosephosphate isomerase gene of Giardia lamblia in formalin-fixed feces. Rev Latinoam Microbiol 49: 5-10.

Monis PT, Andrews R, Mayrhofer G, Ey PL 1999. Molecular systematics of the parasitic protozoan Giardia intestinalis. Mol Biol Evol 16: $1135-1144$.

Ng C, Gilchrist C, Lane A, Roy S, Haque R, Hompt E 2005. Multiplex real-time PCR assay using scorpion probes and DNA captures for genotype-specific detection of Giardia lamblia on fecal samples. J Clin Microbiol 43: 1256-1260.

O' Handley RM, Olson ME, Fraser D, Adams P, Thompson RC 2000. Prevalence and genotypic characterisation of Giardia in dairy calves from Western Australia and Western Canada. Vet Parasitol 90: 193-200.

Pezzani B, Minvielle M, Laplace R, Cotter G, Basualdo J 2003. Presencia de elementos parasitarios en contenido intestinal de múridos de la ciudad de La Plata. Acta Bioquím Clín Latinoam 1: 87.

Pierangeli N, Manacorda A, Soriano S, Pezzani B, Minvielle M, Basualdo J 2003. Estacionalidad de parásitos intestinales en suelos periurbanos de la ciudad de Neuquen, Patagonia, Argentina. Trop Med Int Health 8: 259-263.

Polverino D, Molina NB, Minvielle MC, Lozano ME, Basualdo JA 2004. Técnicas de purificación y ruptura de quistes de Giardia lamblia. Rev Argent Microbiol 36: 97-100. 
Read CM, Monis PT, Thompson RCA 2004. Discrimination of all genotypes of Giardia duodenalis at the glutamate dehydrogenase locus using PCR-RFLP. Infect Genet Evol 4: 125-130.

Read CM, Walters J, Robertson ID, Thompson RCA 2002. Correlation between genotype of Giardia duodenalis and diarrhoea. Int J Parasitol 32: 229-231.

Rimhanen-Finne R, Horman A, Ronkainen P, Haninen ML 2002. An ICPCR method for detection of Crystosporidium and Giardia in natural surface waters in Finland. J Microbiol Methods 50: 299-303.
Thompson RCA 2000. Giardiasis as a re-emerging infectious disease and its zoonotic potential. Int J Parasitol 30: 1259-1267.

van Keulen H, Macechko PT, Wade S, Schaaf S, Wallis P, Erlandsen S 2002. Presence of human Giardia in domestic, farm and wild animals, and environmental samples suggest a zoonotic potential for giardiasis. Vet Parasitol 108: 97-107.

Yong T, Park S, Hwang U, Yang H, Lee K, Min D, Rim H, Wang Y, Zheng F 2000. Genotyping of Giardia lamblia isolates from humans in China and Korea using ribosomal DNA sequences. $J$ Parasitol 86: 887-891. 